\title{
Arabitol and Mannitol as Tracer for Fungal Contribution to Size-Differentiated Particulate Matter of Rural Atmospheric Aerosols
}

\author{
J. Nirmalkar, M. K. Deb, Y. I. Tsai, and D. K. Deshmukh
}

\begin{abstract}
In this study we used biomarkers for analyzing the impact of fungal spore in ambient aerosols collected from rural area of eastern central Indian region during winter 2011.Mannitol and arabitol were used as tracer to estimate the impact of fungal activity in the ambient aerosols in our study site. We present the first estimates for the impact of fungal spores to the ambient aerosols mass loading in the eastern central India. This biomarker are quantified in two particle size fraction i.e. $\mathbf{P M}_{2.5-10}$ (Coarse) and $\mathbf{P M}_{1}$ (Submicron). Mannitol is dominant over arabitol in both two size fraction during winter period. The mass concentrations of these two biomarkers were higher in coarse size fraction as compared to submicron sizes. Strong correlation was found between the mass concentration of mannitol and arabitol in coarse size fraction only, whereas other size fractions were moderately or poorly correlated to each other. These showed that the sources for mannitol and arabitol in coarse size fractionwere similar.
\end{abstract}

Index Terms-PM, biomarkers, mannitol, arabitol, spearman correlation.

\section{INTRODUCTION}

The ambient aerosol (Particulate matter or PM) is considered to be one of the most significant issues due to their many adverse effects towards the human health [1], [2]. PMs are directly originated from sources or form by the interaction of primary pollutant with meteorological parameter like relative humidity, temperature, environmental pressure and rain fall etc. Aerosols are classified as organic and inorganic aerosols [3]. Carbonaceous material participates as a major constituent (70-90\%) of biomass burning aerosols [4]. Approximately $30-75 \%$ of the carbonaceous matter represents the watersoluble organic carbon (WSOC) [5], [6]. The major sources of biomass burnings are uses of wood and coal for cooking and heating activities, and burning of rice straws in agricultural lands after harvesting period [3], [7].

Pulmonary irritation, infection and allergies are some common symptoms which are originated from the biologically active PMs. Particularly, airborne fungi can cause extensive collection of unfavorable response like trigger for asthma attack in humans depending on the type and quantity present. Airborne particles that initiate from living organisms, plants, cell parts, pollen, bacterial and fungal spores are termed bioaerosols or biologically active aerosols [8]. Aerosols containing biological components can

Manuscript received April 2, 2014; revised August 5, 2014.

J. Nirmalkar is with School of Studies in Chemistry, Pandit Ravishankar Shukla University Raipur, India (e-mail: j_nirmalkar@yahoo.com). have a significant effect on human health by causing primarily irritation, infection and allergies [9]. Recent studies have clearly demonstrated that feasible microorganisms present in the atmosphere can contribute to atmospheric chemistry through degradation processes as well as chemical change due to the release or desorption of molecules from microbiological entities [10]. Biological particles contributed an average of $39 \%$ of the organic carbon mass in particles with aerodynamic diameters less than $10 \mu \mathrm{m}$ [11], [12]. Sugar alcohols such as mannitol and arabitol are tracers for biogenic activity associated in aerosols because these carbonaceous materials originated from metabolic activity of fungi, bacteria, small vertebrates and other living system [8]. Mannitol and arabitol are frequently used as a tracer for fungal metabolic activity present aerosols [12]-[14]. Mannitol and arabitol are the biomarker for primary biological PMs and soil resuspension that contains biological materials together with fungi and bacteria [12]. Mannitol and arabitol have significant contribution in $\mathrm{PM}_{2.5-10}$ and $\mathrm{PM}_{2.5}$ aerosols [13]. More recent estimations suggest that fungal spores accounted for $\sim 60 \%$ of coarse atmospheric organic carbon and for $\sim 39 \%$ of the coarse aerosol mass as was measured in Vienna during spring and summer of 2005 [14]. Sugar alcohols are mainly originated from the microorganisms [12]. Feasible fungal spores are present in smoke from outlying biomass fires [15], [16]. Therefore, the main goal of this study is to investigate the influence of fungal metabolic activity using mannitol and arabitol as biomarkers to size-differentiated aerosols collected from eastern central India during winter of 2011. The concern is that even a rural and religious area, which is believed to be environmentally clean, is under the influence of unfavorable response to humans due to fungal metabolic activities. This study will give some clues on how to manage the air quality issue and fill the gap in this research area.

\section{EXPERIMENTAL SECTION}

Atmospheric PMs were collected from rural site of Chhattisgarh, India. Rajim sampling site $\left(20^{\circ} 59^{\prime} \mathrm{N} 81^{\circ}\right.$ $55^{\prime} \mathrm{E}$, Fig. 1), located in Chhattisgarh province, is believed to be a famous religious place due the association of three river i.e. Mahanadi, Pairee and Sodbhadra, and is known as Triveni Sangam. The sampling site is situated at an altitude of $281 \mathrm{~m}$ above from the sea level. This study mainly influence by the biomass burning activities, soil resuspension and frequent agricultural activity that promoting the growth of microorganism like fungal spores. 


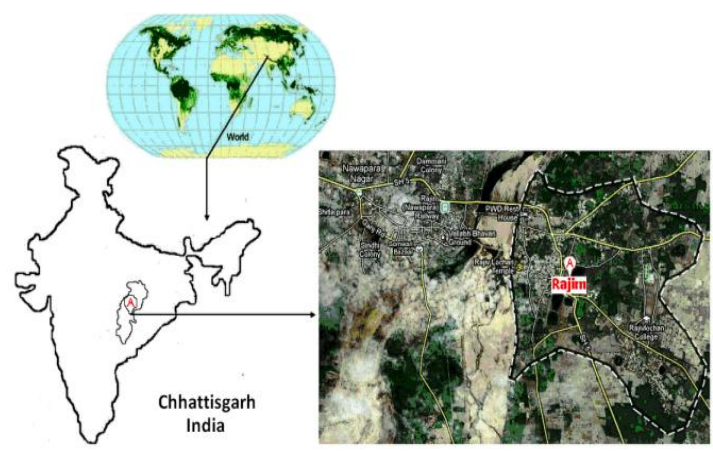

Fig. 1. Study site in eastern central India (Rajim, Chhattisgarh).

The collection of size-differentiated PMs was done at the top of a double-storied building at height of $\sim 15$ meters above the ground level using eight-stage cascade impactor sampler (Modal TE 20-800, USA) with an average flow rate of $28.3 \mathrm{~L} \mathrm{~min}^{-1}$. The initial and final flow rate was checked by dry gas meter (Model 12393959, Invensys (TM) Purchased by Thermo Fisher Scientific). The cut-off diameter of the poles apart stage of eight-stage cascade sampler are; stage 0: 10-9.0 $\mu \mathrm{m}$, stage 1: $9.0-5.8 \mu \mathrm{m}$, stage 2: 5.8-4.4 $\mu \mathrm{m}$, stage 3: 4.4-2.5 $\mu \mathrm{m}$, stage 4: 2.5-2.1 $\mu \mathrm{m}$, stage 5: 2.1-1.0 $\mu \mathrm{m}$ stage $6: 1.0-0.7 \mu \mathrm{m}$ and stage 7: 0.7-0.4 $\mu \mathrm{m}$. Aerosol samples were collected for twenty four hrs, incessantly in the month of October and November 2011. Aerosol particle were collected on pre-treated $80 \mathrm{~mm}$ glass fiber filters.

The mass concentration of size-differentiated PMs was determined by the gravimetric analysis. The filters were placed in desiccators for twenty four hrs before and after the sampling to take out the absorbed water and weighed, after taking the filters out of the desiccators, using an analytical mass balance (Sartorius, Model CP225D) with a reading precision of $10 \mu \mathrm{g}$. Each of the filters including backup filter was analyzed gravimetrically by taking proper care in order to avoid minute divergence in mass measurements. Two of the most important factors to consider mass concentration measurement are variation of weight with temperature (T) and relative humidity (RH). Thus, the filters were first habituated for twenty four hrs at $20^{\circ} \mathrm{C}$ and $35 \% \mathrm{RH}$. All weight measurements were repeated three times to make sure consistency and readings were established when the difference was not beyond from $5 \mu \mathrm{g}$. To ensure the quality of data, field blank samples were also collected during the study period. The gravimetric mass of aerosols $(\mu \mathrm{g})$ was calculated by subtracting the weight of the filter after sampling from that of the previous sampling and the concentration $\left(\mu \mathrm{g} \mathrm{m}^{-3}\right)$ was determined by dividing the aerosol mass by total volume of air sampled $\left(\mathrm{m}^{3}\right)$. After the gravimetric analysis, the sampled filters and field blanks were placed in clean polyethylene (PE) bottles. All samples were kept at $-20^{\circ} \mathrm{C}$ until chemical analysis in order to inhibit fungal growth. The mass concentration of the sampled filters obtained was corrected for field blank values.

Two sugar alcohol frequently used as tracer for fungal metabolic activity in aerosols are chemically analyzed in $\mathrm{PM}_{2.5-10}$ and $\mathrm{PM}_{1}$ aerosols. Organic compounds were extracted from the filter using $10.0 \mathrm{~mL}$ of deionized water (>18.2 MU cm ${ }^{-1}$, Analytical System Model D11901, Barnstead) and a cellulose acetate syringe membrane (C020A025A, $25 \mathrm{mmf}$, pore size $0.2 \mathrm{~mm}$, Advantec) in a PE bottle continuously and agitated for 90 min on a shaker (TS500, Yihder). Extraction was performed in an unlit refrigerator at $4{ }^{\circ} \mathrm{C}$ to prevent the decomposition of extracted organic compound (Tsai et al., 2008). Extracted samples were then stored at $-20^{\circ} \mathrm{C}$. Blank filters were treated in the same way for observe contamination to correct background concentrations. $100 \mathrm{mg}$ of each compound was dissolved in deionized water and the final volume adjusted to $100 \mathrm{~mL}$ for a $100 \mathrm{mg} \mathrm{L}^{-1}$ stock solution. These solutions were stored at $18^{\circ} \mathrm{C}$ until used to make standard solutions and these, in turn, were stored at $4^{\circ} \mathrm{C}$ to prevent degradation during analysis. Sugar alcohols were determined using a Dionex ICS-2500 IC equipped with pulsed amperometric detection (PAD), a GP50 gradient pump coupled to a Teflon injection valve with $400 \mathrm{~mL}$ sample loop, a CarboPac MA1 guard column (50 mm length $\times 4 \mathrm{~mm}$ I.D.) and anion-exchange analytical column $(250 \mathrm{~mm}$ length $\times 4 \mathrm{~mm}$ I.D.), a Dionex ED50 electrochemical detector with a gold working electrode and a $\mathrm{pH}$ electrode as reference. Dissolution of carbonate into $\mathrm{NaOH}$ can hinder the separation and to reduce the potential for this, exposure of $\mathrm{NaOH}$ solutions to atmospheric $\mathrm{CO}_{2}$ was minimized. Method detection limit (MDLs) for mannitol and arabitol varied from $18.8 \mathrm{mg} \mathrm{L}^{-1}$ to $4.76 \mathrm{mg} \mathrm{L}^{-1}$.

\section{RESULT AND DICUSSION}

TABLE I: MASS CONCENTRATIONS AND STATISTICAL PARAMETER OF BIOMARKERS DURING WINTER PERIOD (2011)

\begin{tabular}{|c|c|c|c|c|}
\hline Biomarkers & $\begin{array}{c}\text { Mean } \\
\left(\mathrm{ng} / \mathrm{m}^{3}\right)\end{array}$ & ${ }^{\mathrm{a}} \mathrm{SD}$ & $\begin{array}{c}\text { Range } \\
\left(\mathrm{ng} / \mathrm{m}^{3}\right)\end{array}$ & ${ }^{\mathrm{b}} \mathrm{CV}$ \\
\hline \multicolumn{5}{|l|}{ Mannitol } \\
\hline $\mathrm{PM}_{2.5-10}$ & 1682.2 & 147.0 & $1453-1883$ & 0.09 \\
\hline $\mathrm{PM}_{1}$ & 716.6 & 112.2 & $534-838$ & 0.16 \\
\hline \multicolumn{5}{|l|}{ Arabitol } \\
\hline $\mathrm{PM}_{2.5-10}$ & 265.9 & 101.2 & 114.1-389 & 0.38 \\
\hline $\mathrm{PM}_{1}$ & 101.3 & 66.7 & $11-250$ & 0.66 \\
\hline
\end{tabular}

Atmospheric conditions are dependent on the size distribution and chemical composition of aerosols. According to the recent studies, mannitol and arabitol are used as biomarker of fungal spores (Bauer et al., 2008a). The productions of arabitol and mannitol during winter are stronger than expected. Some fungal spores in smoke cause allergic reactions and activate asthma attack [17]. Fig. 2 and Table 1 shows the mean mass concentration and twenty four hrs variation in mass concentration of biomarker in $\mathrm{PM}_{2.5-10}$ and $\mathrm{PM}_{1}$ aerosols, respectively. Significant variation in the twenty four hrs average concentration of mannitol and arabitol was found during the study period.

Daily average concentrations of these two biomarkers were showed same pattern of spikes. The spikes of coarse peaks were dominant over the submicron spikes. This shows that soil re-suspension is major source of these biomarkers as compared to biomass burning for this sampling area. Airborne fungal spores contribute potentially to the organic carbon of the atmospheric PM, largely in the coarse aerosol[18]. Feasible fungal spores are present in smoke from remote biomass burning [15]. Submicron aerosols were mainly originated from the combustion sources [3]. In Rajim sampling site, biomass i.e., rice straw, wood and cow- 
dung cake are used for cooking and heating in home especially during winter period [3]. The concentration of mannitol ranged from 1453 to $1883 \mathrm{ng} \mathrm{m}^{-3}$ and 534 to 838 $\mathrm{ng} \mathrm{\textrm {m } ^ { - 3 }}$, whereas for arabitol it was varied between 114.1 and $389 \mathrm{ng} \mathrm{m}^{-3}$, and 11 and $250 \mathrm{ng} \mathrm{m}^{-3}$ in $\mathrm{PM}_{2.5-10}$ and $\mathrm{PM}_{1}$, respectively. The mean mass concentration of mannitol and arabitol was higher in coarse particle and this was mainly due to the agglomeration of fungal spores and soil resuspension during the study period. Airborne fungal spores contributed potentially to the organic carbon of the atmospheric PMs, mainly in the coarse aerosol as compared to fine aerosol during winter and this was might be due to the agglomeration of fungal spores [16], [19]. The total concentration of mannitol in both size fractions is high as compared to arabitol. This might be due to the low decomposition rate of vegetative detritus during winter period. One more step is needed for the formation of arabitol as compared to mannitol which is less likely to be found during stable period i.e., winter period. Thermal and photolytic decomposition phenomena during winter period is less due to the low concentration of oxidizing species like $\mathrm{OH}^{-}, \mathrm{NO}_{2}^{-}, \mathrm{SO}_{2}$ and other organic free radical [9], [20], [21]. Considerable mass concentration of mannitol (716.6 $\mathrm{ng} \mathrm{m}^{-3}$ ) and arabitol (101.3 $\mathrm{ng} \mathrm{m}^{-3}$ ) were also found in submicron aerosols due to smoke originated from biomass burning activities during winter. The concentrations of mannitol $\left(21.9 \mathrm{ng} \mathrm{m}^{-3}\right)$ and arabitol $\left(8.3 \mathrm{ng} \mathrm{m}^{-3}\right)$ were also higher during winter in Israel during 2008 and 2009

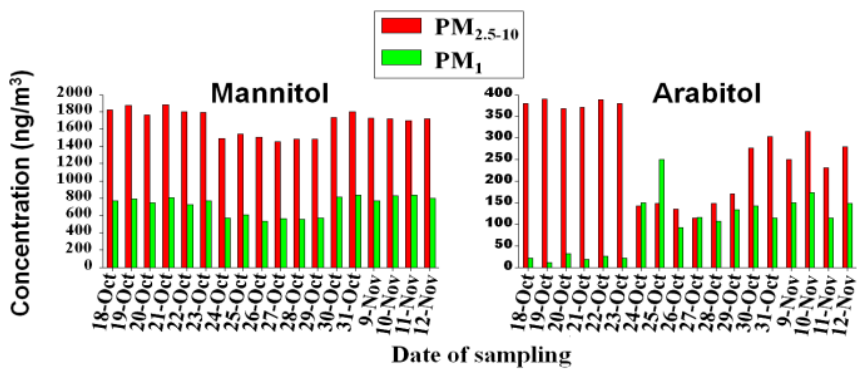

Fig. 2. Daily average concentration of mannitol and arabitol in $\mathbf{P M}_{2.5-10}$ and $\mathrm{PM}_{1}$.

TABLE II: BIOMARKERS AND THEIR CORRELATIONS IN THEIR DIFFERENT

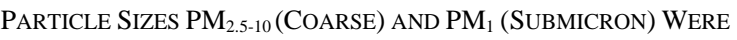
EXAMINED USING SPEARMAN CORRELATION

\begin{tabular}{|c|c|c|c|c|}
\hline \multicolumn{6}{|c|}{ EXIomarker } & $\begin{array}{c}\text { Mannitol } \\
\text { in coarse }\end{array}$ & $\begin{array}{c}\text { Mannitol } \\
\text { in } \\
\text { submicron }\end{array}$ & $\begin{array}{c}\text { Arabitol } \\
\text { in } \\
\text { coarse }\end{array}$ & $\begin{array}{c}\text { Arabitol } \\
\text { in } \\
\text { submicron }\end{array}$ \\
\hline $\begin{array}{c}\text { Mannitol in } \\
\text { coarse }\end{array}$ & $\mathbf{0 . 5 8 *}$ & $\mathbf{0 . 9 0} * *$ & $-0.60^{* *}$ \\
\hline $\begin{array}{c}\text { Mannitol in } \\
\text { submicron }\end{array}$ & $\mathbf{0 . 5 8 *}$ & & $\mathbf{0 . 5 4} *$ & -0.04 \\
\hline $\begin{array}{c}\text { Arabitol in } \\
\text { coarse }\end{array}$ & $\mathbf{0 . 9 0 * *}$ & $\mathbf{0 . 5 4} *$ & & $-0.61 * *$ \\
\hline $\begin{array}{l}\text { Arabitol in } \\
\text { submicron }\end{array}$ & $-0.60^{* *}$ & -0.04 & $-0.61 * *$ & \\
\hline $\begin{array}{l}* \text { Correlation is significant at the } 0.05 \text { level (2-tailed); } \\
* * \text { Correlation is significant at the } 0.01 \text { level (2-tailed). }\end{array}$ \\
\hline
\end{tabular}

Spearman correlation was chosen for explaining the relationship between the biomarkers in size-differentiated aerosols. The result of correlation analysis is given in Table 2. Mannitol and arabitol are highly correlated $\left(r_{\mathrm{sp}}=0.90\right)$ in coarse aerosol and showed their origination from similar kind of sources i.e., re-suspension of biologically active soil. These biomarkers might be originated from metabolic activity of fungal spores present in the atmospheric aerosols [22]. Mannitol found in submicron aerosol was moderately correlated with that found in coarse aerosol. Arabitol in submicron aerosol was negatively correlated with mannitol found in coarse and submicron aerosols and suggested their different emission sources. Biomarkers associated with submicron aerosol are typically originated from combustion of microbial active biomass [15], whereas, biomarkers associated with coarse aerosol are originated from microbial active soil re-suspension [23], [24].

\section{CONCLUSION}

Mannitol and arabitol were quantified in two size fractions i.e., coarse and submicron to estimate the impact of fungal spore to aerosol mass loading during winter of 2011 in rural study site of eastern central India. The results of this study suggested that the biological particles may significantly contribute to the mass loading in atmospheric aerosols. Mannitol (1682.2 $\mathrm{ng} \mathrm{m}^{-3}$ ) and arabitol (265.9 $\mathrm{ng} \mathrm{m}$ ${ }^{3}$ ) were showed higher concentration in coarse particles and indicated that biologically active soil re-suspension and fungal spore agglomeration was common source in this study site. Significant concentration of mannitol (716.6 ng $\mathrm{m}^{-3}$ ) and arabitol $\left(101.3 \mathrm{ng} \mathrm{m}^{-3}\right)$ were found in submicron particles, which was mainly due to the biomass burning activities for cooking and heating purposes in and around the study area. Strong correlation $\left(r_{\mathrm{sp}}=0.90\right)$ was found between mannitol and arabitol in coarse aerosol and indicated similar sources of origin.

\section{ACKNOWLEDGMENTS}

The authors are grateful to Head, School of Studies in Chemistry and School of Studies in Pharmacy, Pt. Ravishankar Shukla University Raipur, Chhattisgarh, India for providing necessary laboratory supports.

\section{REFERENCES}

[1] R. M. Harrison and J. Yin, "Particulate matter in the atmosphere: which particle properties are important for its effects on health?" The Science of the Total Environment, vol. 249, pp. 85-101, April 2000.

[2] E. Oesterling, N. Chopra, V. Gavalas, X. Arzuaga, E. J. Lim, R. Sultana, D. A. Butterfield, L. Bacha, and B. Hennig, "Alumina nanoparticles induce expression of endothelial cell adhesion molecules," Toxicology Letters, vol. 178, pp.160-166, 2008.

[3] J. Nirmalkar, M. K. Deb, D. K. Deshmukh, and S. K. Verma, "Mass loading of size-segregated atmospheric aerosols in the ambient air during fireworks episodes in Eastern Central India," Bull Environ Contam Toxicol, 2013

[4] S. Guofeng, W. Siye, W. Wen et al., "Emission factors, size distributions, and emission inventories of carbonaceous particulate matter from residential wood combustion in rural China," Environ Sci. Technol, vol. 46, pp. 4207-4214, 2012.

[5] I. T. Ying, L. W. Pei, T. H. Yu, and R. Y. Chi, "Anhydrosugar and sugar alcohol organic markers associated with carboxylic acids in particulate matter from incense burning," Atmos. Environ., vol. 44, pp. 3708-3718, 2010.

[6] S. S. Park and S. Y. Cho, "Characterization of Organic Aerosol Particles Observed during Asian Dust Events in Spring 2010," Aerosol Air Qual. Res., DOI: 10.4209/aaqr.2012.06.0142.

[7] W. Elbert, P. E. Taylor, M. O. Andreae, and U. Poschl, "Contribution of fungi to primary biogenic aerosols in the atmosphere: wet and dry discharged spores, carbohydrates, and inorganic ions," Atmos. Chem. Phys., vol. 7, pp. 4569-4588, 2007.

[8] P. D. Filippo, D. Pomata, C. Riccardi, F. Buiarelli, and C. Perrino, "Fungal contribution to size-segregated aerosol measured through biomarkers," Atmos. Environ., vol. 64, pp. 132-140, 2013. 
[9] J. A. Huffman, B. Treutlein, and U. Poschl, "Fluorescent biological aerosol particle concentrations and size distributions measured with an Ultraviolet Aerodynamic Particle Sizer (UV-APS) in Central Europe," Atmos. Chem. Phys., vol. 10, pp. 3215-3233, 2010.

[10] G. Cote, R. Kos, P. Mortazavi, and P. A. Ariya, "Microbial and 'de novo' Transformation of Dicarboxylic Acids by Three Airborne Fungi," Sci. Total Environ., vol. 340, pp. 530-537, 2008.

[11] C. Wiedinmyer, R. M. Bowers, N. Fierer, E. Horanyi, M. Hannigan, A. G. Hallar, I. McCubbin, and K. Baustian, "The contribution of biological particles to observed particulate organic carbon at a remote high altitude site," Atmos. Environ., vol. 43, pp. 4278-4282, 2009.

[12] P. Fu and K. Kawamura, "Diural variations of polar organic tracers in summer forest aerosols: A case study of a Quercus and Picea mixed forest in Hokkaido, Japan," Geochemical Journal, vol. 45, pp. 297 308, 2011.

[13] H. Bauer, M. Claeys, R. Vermeylen, E. Schueller, G. Weinke, A Berger, and H. Puxbaum, "Arabitol and mannitol as tracers for the quantification of airborne fungal spores," Atmos. Environ.,vol. 3, pp. 588-593, 2008a.

[14] H. Bauer, E. Schueller, G. Weinke, A. Berger, R. Hitzenberger, L. Marr, and H. Puxbaum, "Significant contributions of fungal spores to the organic carbon and to the aerosol mass balance of the urban atmospheric aerosol," Atmos. Environ., vol. 22, pp. 5542-5549, 2008b.

[15] S. A. Mims and F. M. Mims III, "Fungal spores are transported long distances in smoke from biomass fires," Atmos. Environ., vol. 38, pp. 651-655, 2004.

[16] H. Bauer, A. K. Giebl, F. Zibuschka, R. Hitzenberger, G. F. Kraus, and H. Puxbaum, "Determination of the Carbon Content of Airborne Fungal Spores," Anal. Chem., vol. 74, pp. 91-95, 2002.

[17] B. Kendrick. (2000). The Fifth Kingdom. Mycologue Publications, Sydney, BC, Canada. [Online]. pp. 126-141. Available: http://www. mycolog.com/

[18] R. Marks, K. Kruczalak, K. Jankowska, and M. Michalska, "Bacteria and fungi in air over the Gulf of Gdansk and Baltic sea," Aerosol Science, vol. 32, pp. 237-250, 2001.

[19] C. Crawford, T. Reponen, T. Lee, Y. Iossifova, L. Levin, A. Adhikari, and S. A. Grinshpun, "Temporal and spatial variation of indoor and outdoor airborne fungal spores, pollen, and (1-3)-b-D-glucan," Aerobiologia, vol. 25, pp. 147-158, 2009.

[20] C. J. Hennigan, A. P. Sullivan, J. L. Collett, and A. L. Robinson, "Levoglucosan Stability in Biomass Burning Particles Exposed to Hydroxyl Radicals," Geophysical Research Letters, vol. 37, no. 9, 2010.

[21] N. Burshtein, Y. N. Lang, and Y. Rudich, "Ergosterol, arabitol and mannitol as tracers for biogenic aerosols in the eastern Mediterranean," Atmos. Chem. Phys., vol. 11, pp. 829-839, 2011.

[22] L. Deguillaume, M. Leriche, P. Amato1, P. A. Ariya, A. M. Delort, U. Poschl, N. Chaumerliac, H. Bauer, A. I. Flossmann, and C. E. Morris, "Microbiology and atmospheric processes: chemical interactions of Primary Biological Aerosols," Biogeosciences Discuss., vol. 5, pp. 841-870, 2008.
[23] M. Claeys, I. Kourtchev, V. Pashynska et al., "Polar organic marker compounds in atmospheric aerosols during The LBA-SMOCC 2002 biomass burning experiment in Rondonia, Brazil: sources and source processes, time series, diel variations and size distributions,"Atmos. Chem. Phys., vol. 10, pp. 9319-9331, 2010.

[24] C. L. Heald and D. V. Spracklen, "Atmospheric budget of primary biological aerosol particles from fungal spores," Geophysical Research Letters, vol. 36, 2009.

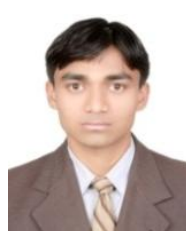

Jayant Nirmalkar has completed his M.Sc. degree in inorganic chemistry in 2009 and is presently working as a Ph.D. student under the supervision of Prof. Manas Kanti Deb at School of Studies in chemistry, Pandit Ravishankar Shukla University Raipur, India. His research interests are characterization and seasonal variation of anhydrosugars, sugar alcohols and dicarboxylic acid in size segregated aerosols.

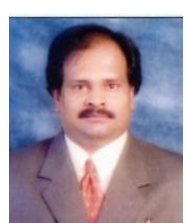

Manas Kanti Deb is a professor of analytical chemistry at School of Studies in Chemistry, Pandit Ravishankar Shukla University Raipur, India. He has got the JSPS fellowship under bilateral exchange program in 1999 and Royal Society London fellowship under interacademic exchange program from 2007 to 2008 . His research is focused on analytical chemistry, environmental chemistry and nano particles and its application.

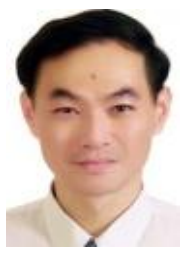

Ying I. Tsai is a professor and the chair of the Department of Environmental Resources Management, Chia Nan University of Pharmacy and Science, Taiwan. He had joined Taiwan Association for Aerosol Research (TAAR), the Chinese Institute of Environmental Engineering, European Aerosol Assembly (EAA), and the Honor Society of Phi Kappa Phi. His research is focused on aerosol chemical characterization, source apportionments of aerosol, long-range transport of aerosol, environmental nanotechnology, optical characterization, air resources management.

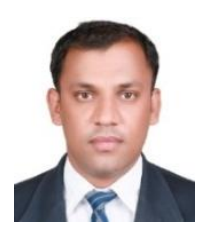

Dhananjay K. Deshmukh has completed his M.Sc degree in organic chemistry and is presently working as a Ph.D. student under the supervision of Prof. Manas Kanti Deb at School of Studies in Chemistry, Pandit Ravishankar Shukla University Raipur, India. His research interests are characterization and seasonal variation of low molecular weight dicarboxylic acid in size segregated aerosols. 